\title{
Environmental Risk - Sensitive Assessment Methodology for Sustainable Land Use Planning in New Egyptian Communities (Case study: New Sphinx City)
}

\author{
Seham Mostafa Qutb ${ }^{1, \square}$
}

\begin{abstract}
Cities in the developing world face increased disaster risk, and they face a high potential of ecosystem and economic losses due to natural disasters, that is why each element that contributes to natural hazards must be investigated as part of the risk assessment process. This helps identify potential hazards to which urban areas are vulnerable and assessing the vulnerability of people and ecosystems to these risks.

Taking an environmental land use planning assessment focuses on how planners guide the physical and ecological shape of cities and regions through state and local policy intervention into land-use patterns and environmental protection.

It is necessary to be able to assess risks, therefore the risksensitive land use planning assessment approach is a tool of Environmental Land use Planning Assessment, which integrates ecosystem services and risk exposure in risk assessment not only risk exposure as traditional risk assessment approach.

So, risk-sensitive land use planning assessment provides a comprehensive approach for addressing compromises between competing land uses and assisting in the support of planning and development decisions, this is through tools including geographic information systems, that are used to aid in Environmental Land use Planning Assessment and to make it more common among policymakers as a key concept in decision-making,

The research aims to propose methodology for Environmental Risk Assessment that can be useful in planning and steering sustainable regulations and proposed environmental land uses planning alternatives in new communities.
\end{abstract}

Keywords: Environmental Land use planning assessment, Sustainable regulations, Risk-sensitive assessment, new communities, Geographic information system (GIS), Ecosystem services assessment

\section{Introduction}

The primary goal of land use planning as a planning and

\footnotetext{
Received:9 October 2021 / Accepted:16 November 2021

$\square$ Corresponding Author Name, Seham Mostafa Qutb

E-mail: seham.mostafa87@gmail.com

1. Lecturer, Environmental Planning Department, Faculty of Urban Planning, Cairo University (Egypt).
}

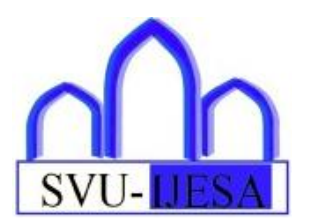

decision-making process is to create an enabling environment for sustainable development of land resources that meets people's needs and demands' (FAO and UNEP, 1999), therefore land-use planning has become a requirement for spatial development that aims for social, ecological, and economic sustainability [1].

However, there are various approaches to Environmental Land use Planning Assessment approach in communities, but they may fail to consider the linkage and relationships between the assessment of ecosystem services and environmental risks, causing the Risk-sensitive land use planning assessment approach to appear in September 2015 as a guide to other plans and policies by recommending "safe areas" for infrastructure and economic activity investments, natural resource conservation, and urban development [2]

A useful approach for making sustainable regulation Risksensitive land-use planning approach is based on the principle that development should be avoided in high-risk and high-value ecosystem services "hot spots" that are vulnerable to natural hazards and ecosystem services value to the greatest extent possible. [3]

Risk and ecosystem services assessments are included as part of the Risk-sensitive land use planning assessment approach. So, an ecosystem services assessment can help to reveal or recognize impacts - particularly indirect and cumulative ones - that might otherwise go unrecognized during the assessment process. [4]

Consequently, the method of Risk-sensitive land use planning assessment approach is accomplished by connecting and demonstrating the relationships between the assessments of ecosystem services exposure and risk exposure (V) in environmental risk assessment Variables, in addition to determining risk hazard (h), therefore this will enable planners to identify sustainable regulations.

\subsection{Concept of Risk-sensitive Land use planning assessment approach}

Natural hazards are natural phenomena that can cause death or property damage [5] [1] [1] experts and scholars both at home and abroad have various opinions on what constitutes a risk. Haynes, the first to propose the concept of risks, stated that risks are defined as the possibility of loss [6] [1].Risks, according to the International Organization for Standardization, are the consequences of uncertainty [7] Deng et al. defined risks as the possibility 
of unfavorable events and the resulting damage [8]

According to natural disaster events assessment can be used to inform urban development strategies and policies, similarly, risk data can be used for land-use planning and design. Measures to reduce the environmental risk that can be used to build urban resilience [9] [10]

Consequently, Risk assessment is the process of determining the probability of a risk occurring and the impact that event would have if it actually occurred. This is essentially a "cause and effect" investigation. The "cause" is the potential event, whereas the "effect" is the potential impact on a project if the event occurs. A risk assessment is comprised of two components. The first is the probability, which is a probability that an event, or risk, will occur [11]

However, the traditional risk assessment approach occurs within the context of disaster risk management, which identifies the capacities and resources available to reduce the identified levels of risk or the potential effects of a disaster (v), and takes into account the planning of appropriate risk mitigation measures, the risk characterization from the review of hazards $(\mathrm{H})$, and Vulnerability (V), as shown in fig (1).

The risk-sensitive Land Use Planning assessment

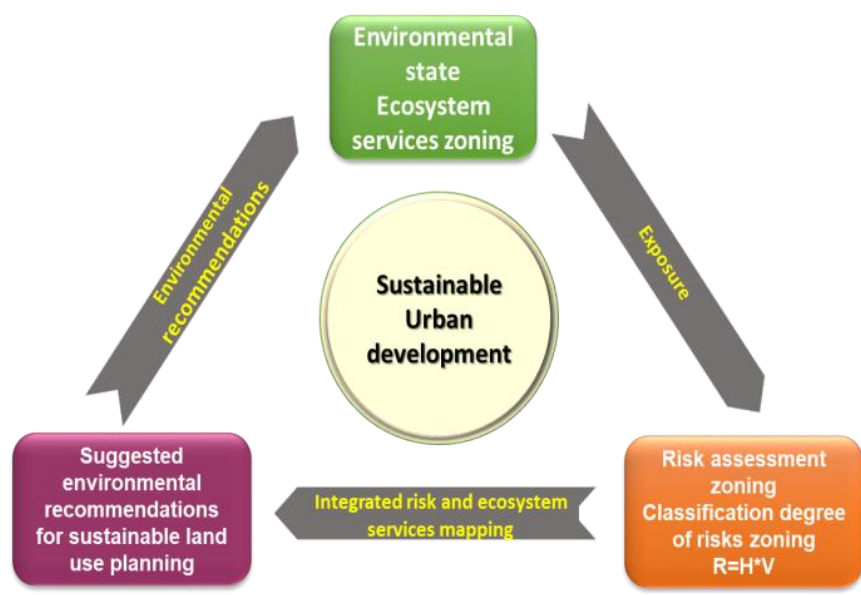

Fig.1 A proposed methodology for environmental risk assessment based on Environmental Risk-sensitive approach for sustainahle land use nlannino [11] [13]

approach refers to the process of integrating ecosystem services assessment and risk assessment as a vulnerability of risk parameters (v) not only risk assessment as a vulnerability into risk assessment [12][13]

This will enable to identify the goals of integrating risksensitive assessment into land-use planning are as follows:
- Make spatial development decisions based on a wide range of data, including ecosystem services and disaster risk information

- integrating ecosystem services and risk parameters into land-use planning

- To ensure that assets are located in appropriate areas

- To reduce the vulnerability of communities

- To avoid the creation of new hazards or risks

- Risk identification and mitigation plan recommendations

\subsubsection{Hazard of risk assessment}

A natural hazard is a potentially dangerous natural phenomenon that can cause bodily harm or loss of life, property damage, infrastructure damage, and economic disruption. [14][15]

The hazard event is not the only source of risk, and there is a high degree of certainty that the severity of the consequences is determined in part by the vulnerability and exposure of societies and social-ecological systems. [16]

\subsubsection{Vulnerability of risk-sensitive assessment}

Vulnerability of risk-sensitive assessment include Ecosystems Services assessment and risk assessment Vulnerability of natural risk assessment

Early definitions of vulnerability in the context of disaster risk management were based on the physical resistance of engineering structures [17], but more recent definitions link vulnerability to characteristics of social and environmental processes.

Vulnerability is the proclivity of exposed elements such as humans, their livelihoods, and assets to suffer negative consequences when impacted by hazard events, so Vulnerability can be thought of as situational, interacting with a hazard event to generate risk [18] [19]

\section{Vulnerability of Ecosystems Services assessment}

The ecosystem services (ES) concept has been globally acknowledged to play a crucial role in economic, environmental, and social wellbeing - the three pillars of sustainable development [5]

Consistent with the Millennium Ecosystem Assessment (2005) framework, the USAID Biodiversity Policy (2014) identifies four categories of ecosystem services. They include: 1) provisioning goods or services, such as food, fish, water, fuels, timber, and fiber; 2) regulating services, such as purification of air, flood protection, waste absorption, and climate regulation; 3) cultural services that provide aesthetic, spiritual, and recreational benefits; and 4) supporting services needed for the production of all other ecosystem services, such as crop pollination, soil formation, carbon sequestration and nutrient cycling [15] [20] as in fig 2. : 


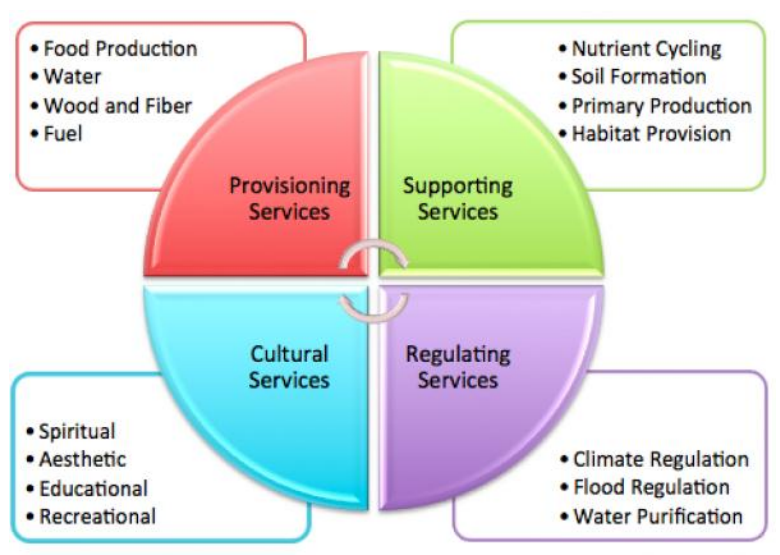

Fig.2 Ecosystem services assessment [20]

People manage ecosystems primarily to meet food, fiber, and fuel needs, in addition to ecosystem services assessment helps to identify impacts and project dependencies that might otherwise go unnoticed or unaddressed by gaining a better understanding of project impacts and dependencies, while also supporting environmental policy and development objectives [4]

Importantly, there is a pressing need to identify the synergies between ecosystem services in order to support risk-sensitive assessment policy and priorities restoration efforts, Consequently, Ecosystems Services assessment is one of the keystone actions to support policy decisions on urban sustainability and natural resource management (21)

So that Risk Sensitive Land Use Planning approach guides relevant risk reduction measures in order to protect and prioritize investments in urban development and infrastructure that can use conventional land use planning approaches by integrating two additional considerations [22][12]Finally, Risk Sensitive Land Use Planning approach provides guidance to other plans and policy instruments by recommending "safe areas" for infrastructure and economic activity investments, natural resource conservation, and urban development [2]

As a result, Risk zoning promotes community resilience by providing data, promoting collaboration, and supporting long-term hazard mitigation planning and help to ensure that policy decisions are prioritized in ways that address the most serious risks with the most appropriate prevention and preparedness measures, and can also serve as a tool of mutual support in the process. [23][24][25]

\section{Material and method:}

A Methodology for Environmental Risk Assessment for
Sustainable Urban Development of New Egyptian
Communities "new Sphinx city Case study "The
research A Methodology for Environmental Risk
Assessment for Sustainable Urban Development of New Egyptian Communities in order to ensure the sustainability integrated between ecosystem services and risk assessment in Environmental Land use planning assessment for the new Egyptian cities to reach a set of environmental decisions in ensuring the sustainability of the management land uses, which will be accomplished in three main phases: First phase introduction of city and its importance, the second phase environmental risk-sensitive assessment and the third phase: sustainable regulations for sustainable land-use planning

This it will be tested on the case of the city of Sphinx according to the stages shown in fig 3. And that can generalize the framework to new Egyptian cities with a vulnerable agricultural ecology. Rainstorms, in particular, are a part of the natural environment.

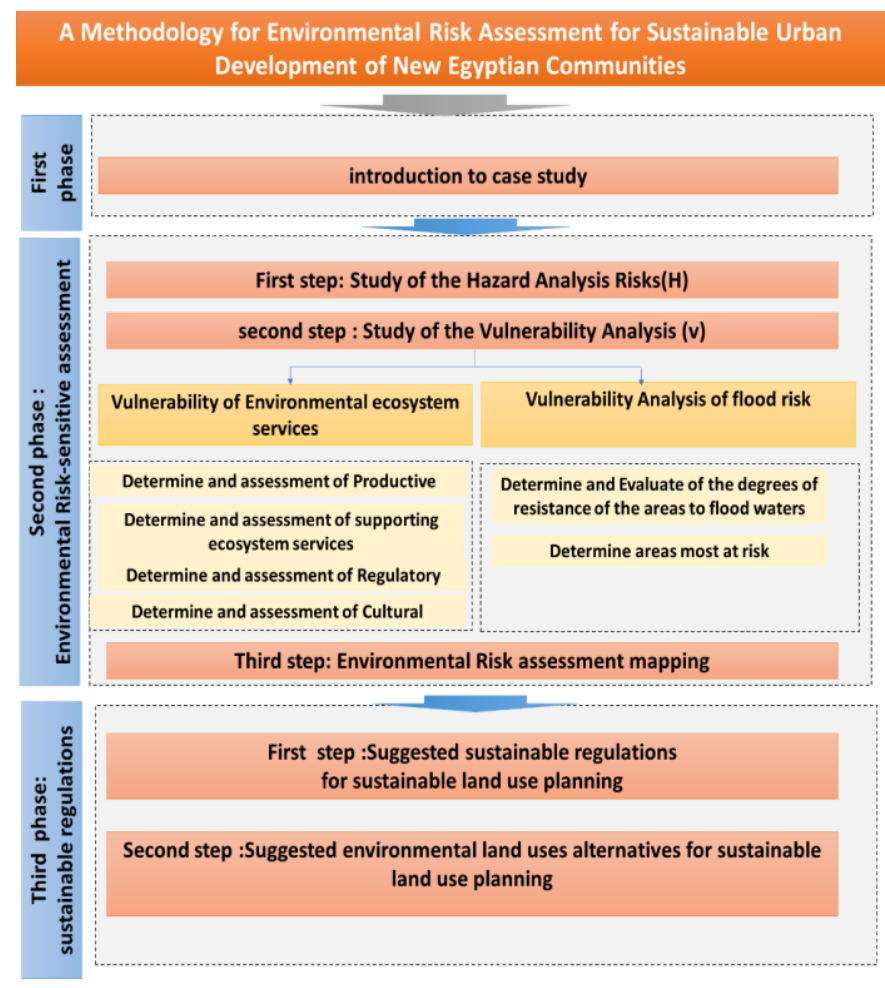

Fig.3 A Methodology for Environmental Risk Assessment of Sustainable Urban Development in New Egyptian Communities

It will be tested on the case of the city of Sphinx according to the stages shown in the following figure, and that can generalize the methodology to new Egyptian cities.

\subsection{First phase: Introduction to the study area}

The New Sphinx City is one of the integrated urban communities of the fourth generation of the new Egyptian cities, which are numbered 14 cities at the state level, including six new cities of the fourth generation in the Greater Cairo Region, The New Sphinx City is one of 14 new Egyptian cities in the fourth generation, with six new 
cities in the Greater Cairo Region (the New Administrative Capital, New Obour, New Capital Gardens, New 6th of October, October Gardens, and New Sphinx). Sphinx is also the second city, after the new administrative capital, to have an international airport among the 14 new fourth-generation cities that have been created. The pyramids and the Grand Egyptian Museum are also nearby

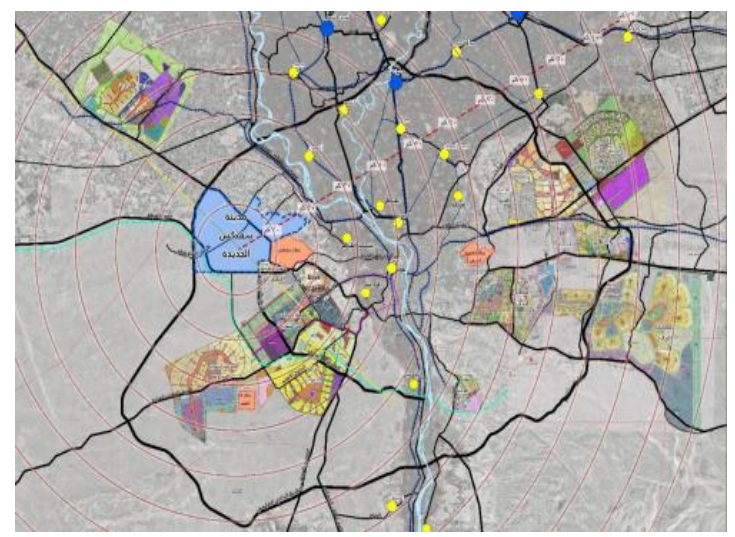

Fig.4: location of Sphinx's new city [26]

\subsection{Second phase: Environmental Risk Sensitive assessment}

The Hazard Analysis $(\mathrm{H})$ research, which is altitudes and terrain, and the Vulnerability Analysis (V), which is represented in the places at risk, will be used to analyze the risk flooding in the new city of Sphinx and assessment of ecosystem services.

2.2.1First step: Study of the Hazard Analysis Risks (H) To research the threat and determine its severity, it is vital to understand its history and whether it has occurred previously, as well as to examine its repercussions and establish standards for future protection. In the case of Wadi Al-Fargh, a flash flood on November 4, 2015 wreaked havoc on the area of Wadi Al-Natrun and Wadi Al-Fargh. Where the two processes of runoff and water inundation caused immediate damage, It also shows the pattern of precipitation intensification, since the rain lasted 17 hours at a rate of (25 to $30 \mathrm{~mm} /$ hour) [27] [1]

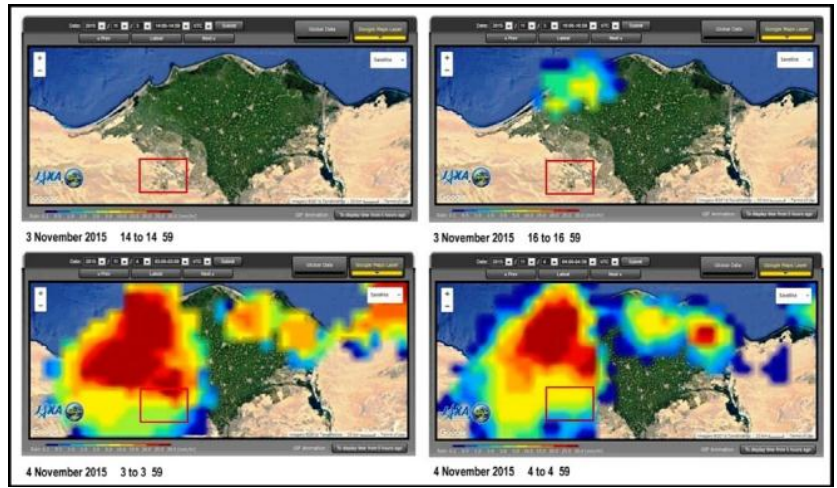

Fig 5. in 2017, the weather in Wadi Al-Fargh deteriorated
The majority of the immersion takes place in the depressions' floors. In Wadi El-Natrun, significant increases in existing lake areas were recorded, as well as the production of new Lakes, as in fig6.

The construction of 22 ephemeral ponds in Wadi Al-Fargh as a result of the flash flood. The three largest basins are located at the entrance to Wadi Al-Fargh in the northwest depression. Floodwaters from three drainage basins feed this area (Wadi Minqar Al Rass, Wadi Iwan, and Wadi Abu Melha). 271 acres of cultivated land were damaged as a result of one pivot farm being encircled in a circle. Most of the ponds in the central region, on the other hand, are located above barren ground. Following the flood, 19 new important farms arose in this area, as shown in the fig(6).

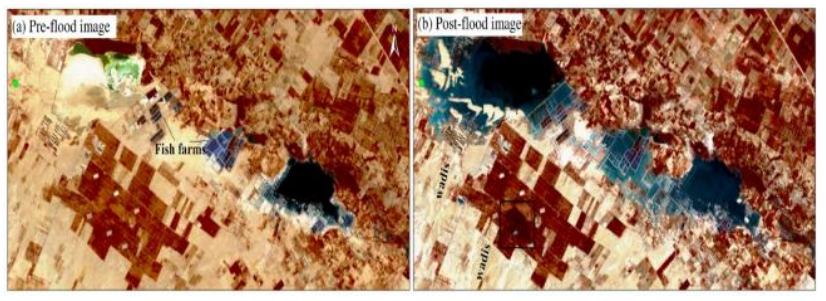

Fig.6 the torrent was raised near the valley's entrance using arcgis [27]

Wadi Saber is on the western shelf of Wadi Al-Farij, the drainage basin is located in Wadi Saber. It is $25 \mathrm{~km}$ in size. Small fruit and vegetable farms make up the majority of agricultural land use, flood damage downstream (garden vine site $30^{\circ} 12^{\prime} 44.8^{\prime \prime} \mathrm{N} 30^{\circ} 17^{\prime} 02.1^{\prime \prime} \mathrm{E}$ ): This 20 -acre farm is located at $30^{\circ} 12^{\prime} 44.8^{\prime \prime} \mathrm{N}$ and $30^{\circ} 17^{\prime} 02.1^{\prime \prime} \mathrm{E}$. Vineyards and green bean harvests have been damaged by runoff. It wreaked havoc on farmland and irrigation systems, damaging around 2 acres of vines. As shown in the next section, water is wetted in the soil up to a depth of 1.7 meters. The restoration will cost 5,000 pounds per acre, according to the owner, and will include replacing lost soil and constructing a new irrigation system, as shown in the figure 7.

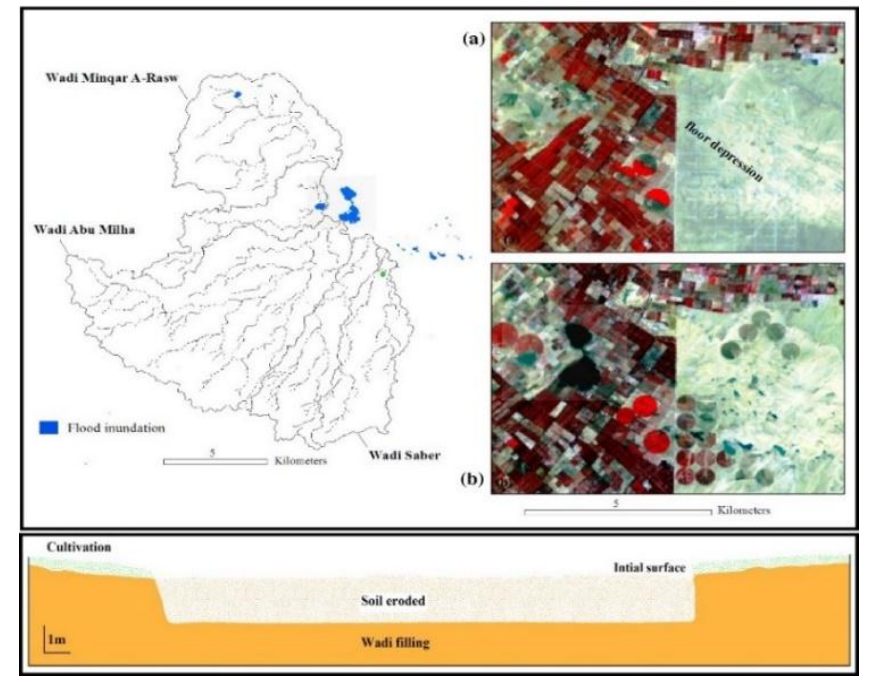

Fig 7. Wadi Saber was raised by the threat of excessive rain 
The water caused havoc on the Daltex farm, which covers over 7000 acres. It is made up of three agricultural basins and 24 core axes. This large farm is located west of Jabal Abu Melh, in a dip connecting to Wadi Al-Fargh. Water inundation harmed $2 \%$ and $9 \%$ of the central axis, respectively. The storm also flooded 5.7 acres of the huge cultivated basin, causing direct damage. The water was taken from the deltex depression's small valleys, as in fig 8.
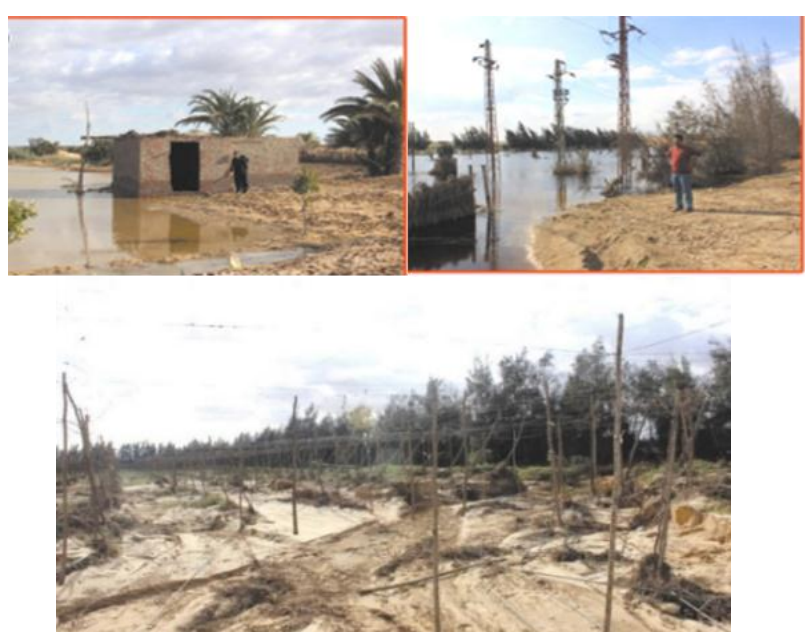

Fig 8. On deltex fields, the effects of the threat Of severe rain

The stream outlet's danger was assessed using environmental surveys of topography, trends, and soil, as well as proximity to the danger, and a relative weight was assigned to each element based on the priorities of the assessment of the study site's environmental factors to determine at a classification of areas according to risk levels, as shown in fig9. and table 1.

Table 1. The basis for classifying areas according to degrees of risk rain.

$\begin{array}{ccccccl}\text { Area } & \text { Soil (5) } & \begin{array}{c}\text { Inclinations } \\ (10)\end{array} & \begin{array}{c}\text { Topography } \\ (10)\end{array} & \begin{array}{c}\text { Proximity to } \\ \text { danger (25) }\end{array} & \begin{array}{c}\text { Total } \\ (50)\end{array} & \text { degrees of risk } \\ \text { A } & 3 & 5 & 10 & 25 & 43 & \begin{array}{l}\text { more dangerous } \\ \text { areas }\end{array} \\ \text { B } & 3 & 5 & 8 & 20 & 36 & \text { Medium risk areas } \\ \text { C } & 3 & 5 & 3 & 12 & 23 & \text { safe areas }\end{array}$

the risk flooding in the new city of Sphinx; the second is the assessment of ecosystem services.

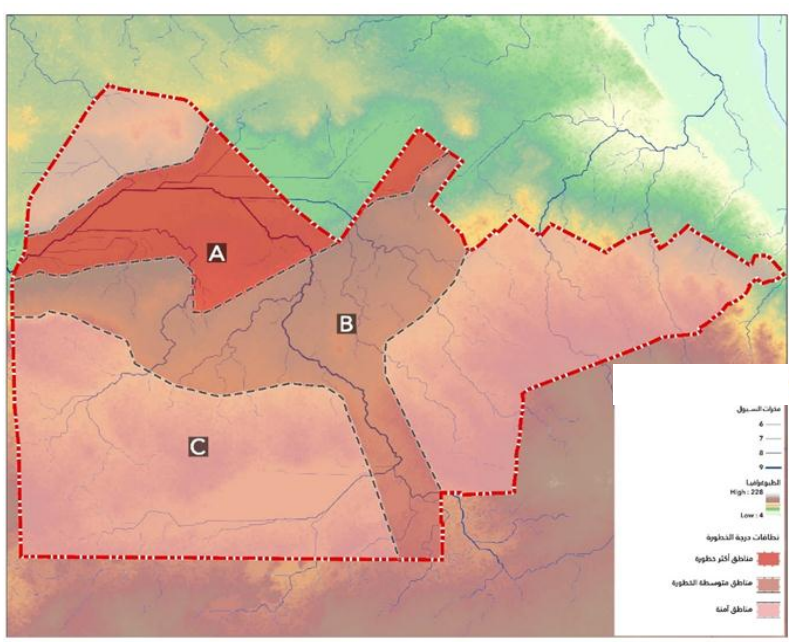

Fig 9. Hazard Analysis mapping using arcgis

\subsubsection{Second step: Study of the Vulnerability (v)}

The Vulnerability Analysis (V), which is represented in two themes; the first is the places at risk, will be used to analyze

\section{A. Vulnerability of Environmental ecosystem services assessment}

- Determine and assessment of Productive Ecosystem The agricultural activity, which is the principal activity and usage in the new city of Sphinx, represents the producing services. The overall agricultural lands are 40.5 thousand feddans, or 53 percent of the total. The city's agricultural crops are diverse, as $\mathbf{s}$ in Table 2,3. as is the degree of producing merit in the city

Table 2. Land productivity rating [26]

\begin{tabular}{|l|l|}
\hline Agricultural crops & The area in acres \\
\hline Land devoted to agriculture & 15168.6 \\
\hline Below-marginal-production land & 12513.5 \\
\hline Lands that have attained their maximum & 17108.8 \\
\hline Yield high productivity Land & 16.9 \\
\hline
\end{tabular}


Table 3. At the level of individual holdings, crop [26]

\begin{tabular}{|l|l|}
\hline The crop & The area in acres \\
\hline Feed & 330.23 \\
\hline Commercial & 220.97 \\
\hline Vegetable & 4626.06 \\
\hline Palm & 1136.87 \\
\hline Roses & 47.15 \\
\hline Decoration Plants & 7572.93 \\
\hline Decorations and trees & 105.89. \\
\hline Medicinal and aromatic & 119.20 \\
\hline Fruit & 11855.39 \\
\hline Crop variety & 446.06 \\
\hline Traditional crops & 225.49 \\
\hline
\end{tabular}

In the study area, there is also animal production, which is represented by animal farms with a flat area of 3692 acres, as in Table 4. With a flat area of 69 percent of the area allocated for poultry and animal production operations, the city's most important animal and poultry production farms are focused in poultry production farms. This is owing to the presence of delta poultry farms and Rolly Poultry farms, which is one of Egypt's largest animal production firms.

Table 4. Livestock and poultry farms

\begin{tabular}{|c|c|c|}
\hline Types & The area & The number \\
\hline Animal production farms & 580 & 20 \\
\hline Poultry production farms & 2542 & 99 \\
\hline Chicks lab & 500 & 1 \\
\hline Fish farms & 17 & 6 \\
\hline Ostrich farms & 15 & 2 \\
\hline Rabbit farm & 11 & 1 \\
\hline Dog farm & 10 & 1 \\
\hline Hatchery lab & 17 & 1 \\
\hline $\begin{array}{l}\text { - Determine and } \\
\text { ecosystem services } \\
\text { Soil in the New Sphi }\end{array}$ & $\begin{array}{l}\text { assessment } \\
\text { e New Sphinx }\end{array}$ & of supporting \\
\hline \multicolumn{3}{|c|}{$\begin{array}{l}\text { The supporting services in the new city of Sphinx are } \\
\text { represented in the soil formation, which contains a } \\
\text { diversity and difference in the nature of the soil, which is } \\
\text { divided into lands with Nile sediment soil, lands with } \\
\text { shallow or rocky clay sands (sandy clay soil), and lands } \\
\text { with gravel soil and sand dunes, the soil is influenced by } \\
\text { the study area's nature, which combines areas affected by } \\
\text { agricultural backs and desert lands, depending on the } \\
\text { study area's position. In general, soil does not pose a } \\
\text { significant impediment to urban growth }\end{array}$} \\
\hline
\end{tabular}

\section{Different habitats}

Due to the study area's location within the largely homogeneous Greater Cairo region and its proximity to the Western Desert, the city has different habitats represented in the animal and plant wealth present in it, and this has a clear impact on the plant and animal environment in it, as it is considered a mixture between a desert environment and an agricultural back, where there is a diversity of plant and animal life, which is represented in agricultural environments (crops vary between field crops, fodder crops, vegetables, and fruit trees), desert environments are more diverse in terms of plant and animal life (containing a group of rare plants(27)(30)

Mammals in the study area include rodents such as mice, rats, and weasels, and certain species of this order can be found coexisting in populated areas and vacant lands within residential blocks, as well as carnivores such as foxes, jackals, and cats, as well as flying mammals. Fruit bats are among them, and because plant and animal life cohabit in the desert and agricultural ecosystems, they coexist in the study region. However, some of them are threatened by encroachment and urban growth within the study's scope, Flora refers to the natural plants that grow in a certain geographic or political area; it excludes species that have been introduced from other places for commercial exploitation or cultivation for decorative purposes, The plants are represented in the study area.

Water: It faces a shortage of potable surface water as well as high salinity in groundwater as it moves from one part of the city to another.

\section{- Determine and assessment of Regulatory Ecosystem} Services in Sphinx City

Climate: The city of New Sphinx has a climate that is nearly uniform throughout the year, with a few differences from one season to the next, as well as according to the city's

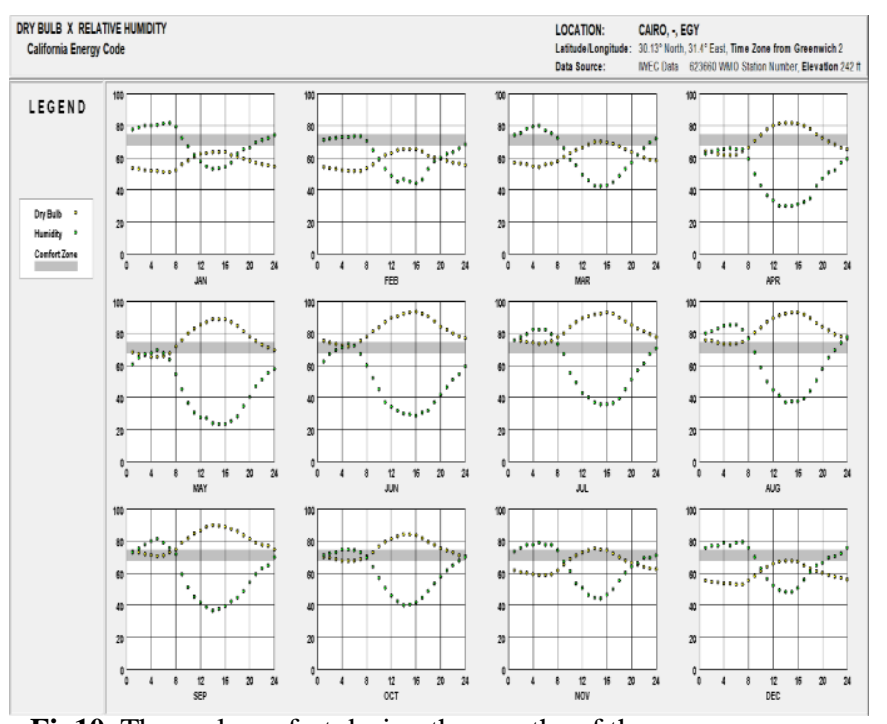

Fig10. Thermal comfort during the months of the year 
location, as it is not located near a river, and thus does not face the risk of flooding, but it is exposed to the risk of torrential rain, which is one of the most serious risks that it faces the months 4-5-6-7-8-9 have thermal rest in some hours of the day, while the months 10-11-12-1-2 have thermal rest in most hours of the day, as in figure 11.

As a result, it is possible to rely on thermal comfort to settle some economic activities, such as hospital tourism, in order to take advantage of the city's thermal comfort. It's also important to stick to the guidelines for preserving thermal comfort.

\section{Risks}

There are several main torrent drains, and according to the topography of the site, the torrent originates in the city's south and southwest, flowing eastward to a low area known as Wadi Al-Fargh, is a contiguous depression that runs parallel to Natron in a SE-NW direction. It stretches about 22 kilometres. In the northwest part, the trough's maximum width (less than $10 \mathrm{~m}$ circle) is $4.8 \mathrm{~km}$. From the east, north, and west, three drainage basins surround the valley. It has a view of three hills on the western and northern sides: Jabal Abu Maleh is 190 metres above sea level. Jebel Quneitra is 196 metres above sea level and moored berth +161 metres from the nearest land.

They are the headwaters of valley networks that flow down to the drainage basin's floor. Because it was mostly deserted until 2000, it was given the name Wadi Al-Fargh, as in fig 11.

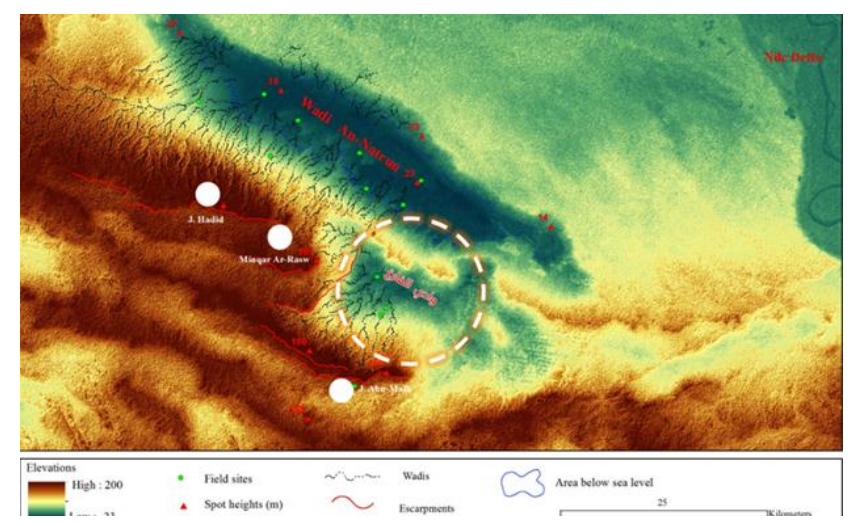

Fig11. The city's location is in a valley (wadi Fargh)

\section{- Determine and assessment of Cultural Ecosystem Services in Sphinx City}

\section{Aesthetic}

The city is in the northwest of the Greater Cairo Region, which is characterized by flat desert areas on the region's edges, especially the western ones, with the existence of certain hills and highlands to the expansion of depressions below sea level.

The city is characterized by a set of topographical characteristics that characterize the Western Desert, which can be summarized by the city's most important topographical characteristics in the flatness of the plains to a large extent, characterizing plain areas with good soil suitable for agriculture, followed by various sediments of sand, clay, and limesto, In terms of the city's topography, around $30 \%$ of the city is considered flat and low-rise areas,

With elevations ranging from 60 to 80 meters, and $70 \%$ of the city is considered medium-altitude areas, with elevations ranging from 60 to 80 meters and $70 \%$ of the city is considered medium-altitude areas, with elevations ranging from 60 to 80 meters, as in fig12.

The aesthetic, spiritual, and recreational values represented in the formation of the topography of the land from highs and lows with the presence of agricultural lands and places of water in times of torrential rains, which helps the presence of these elements to create the opportunity for the presence of environmental tourism in the study area, are represented by the aesthetic, spiritual, and recreational values represented in the formation of the topography of the land from highs and lows with the presence of agricultural lands and places of water in times of torrential rain.

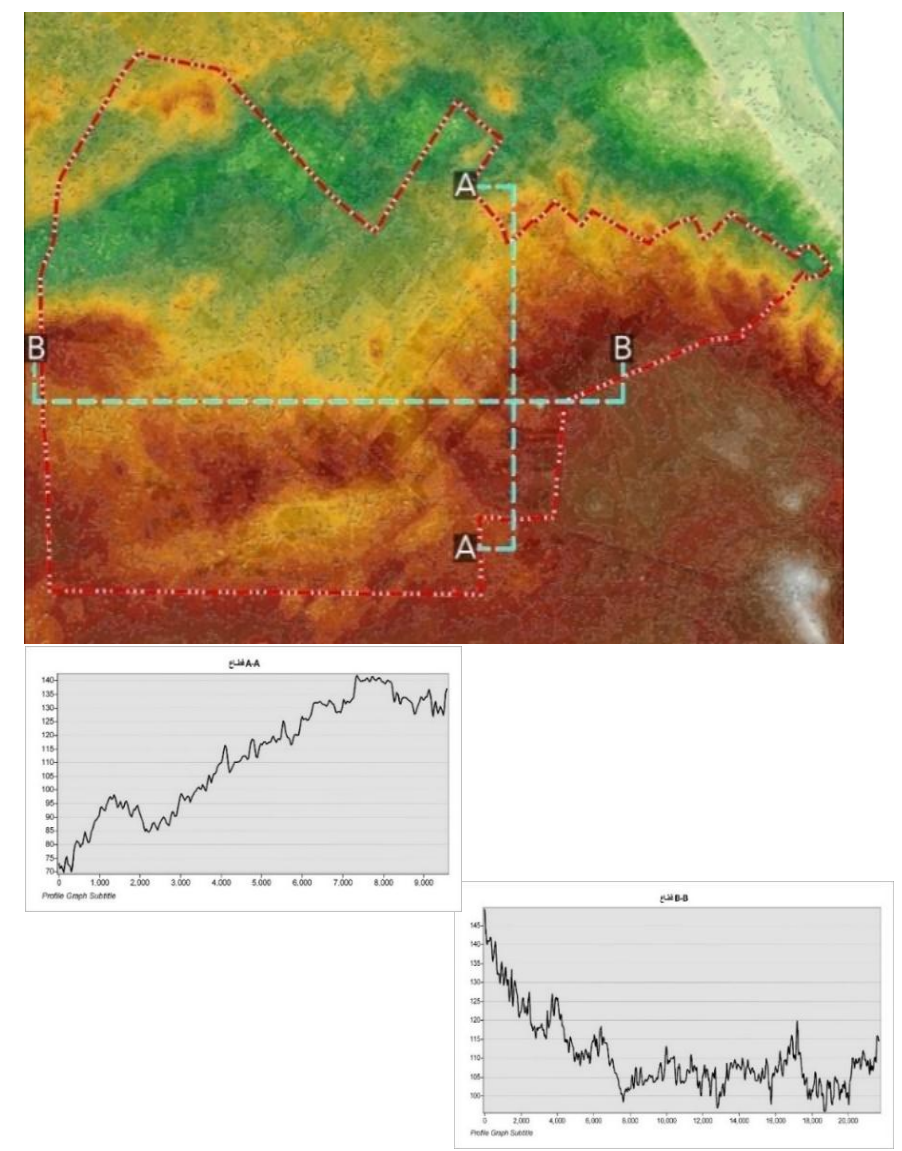

Fig12. Topography of the study area 


\section{- Ecosystem Services assessment in Sphinx City:}

\begin{tabular}{|c|c|c|c|c|c|c|c|c|}
\hline \multirow[t]{2}{*}{ Areas } & \multicolumn{2}{|c|}{ Cultural Services } & \multicolumn{2}{|c|}{$\begin{array}{l}\text { Regulatory } \\
\text { Services }\end{array}$} & \multicolumn{3}{|c|}{ Supportive Services } & \multirow{2}{*}{$\begin{array}{l}\text { Productive } \\
\text { Service } \\
\text { Productiv } \\
\text { elements }\end{array}$} \\
\hline & $\begin{array}{r}\text { water } \\
\text { recreation } \\
\text { al }\end{array}$ & aesthetic & climate & risks & $\begin{array}{l}\text { different } \\
\text { habitats }\end{array}$ & water & Soil & \\
\hline A & $\rightarrow$ & لا & $\rightarrow$ & $\pi$ & $\pi$ & $\pi$ & $\pi$ & $\pi$ \\
\hline B & $\rightarrow$ & $\rightarrow$ & $\rightarrow$ & $\pi$ & $\rightarrow$ & $\rightarrow$ & لا & $\rightarrow$ \\
\hline C & $\pi$ & $\pi$ & $\rightarrow$ & لا & $\rightarrow$ & $\rightarrow$ & $\rightarrow$ & $\rightarrow$ \\
\hline
\end{tabular}

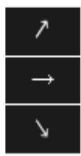

High impact

Medium impact Low impact

$\begin{array}{lc}\text { A } & \text { High } \\ \text { B } & \text { medium } \\ \text { C } & \text { medium }\end{array}$

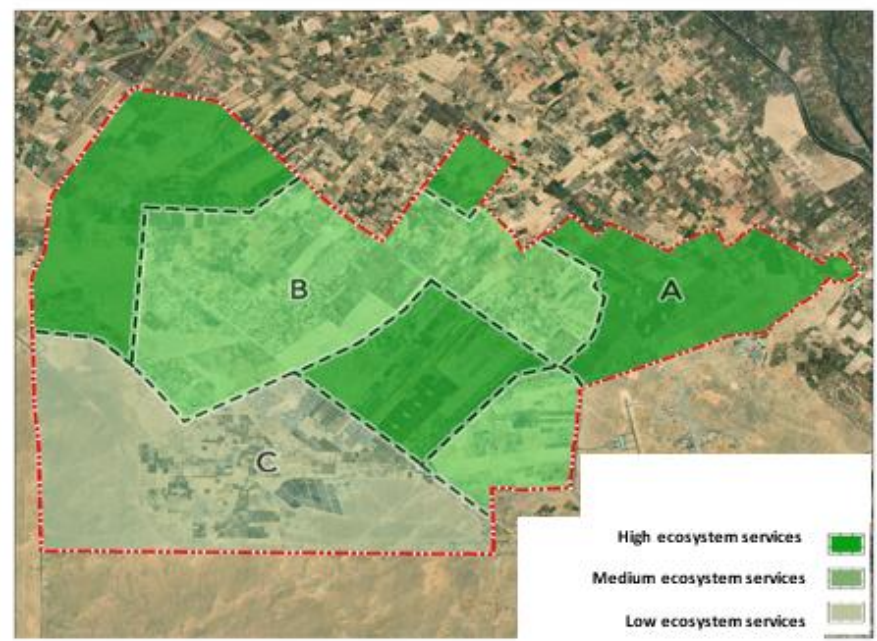

Fig 13. . Ecosystem services assessment mapping in sphinx

\section{B. Study of the Risk Vulnerability Analysis (v)}

The places least resistant to the danger of torrential rain, which are mainly the areas located in the precincts of the torrent's exit or closer, and the areas most exposed to the torrent's exit, which must be taken into account while settling the proposed uses in the plan, resulted from that stage.

A risk assessment map was prepared and access to determining the degrees of risk and determining the buffer zones that will be left as a sanctuary for floods was managed to gain from the study of Hazard Analysis (H) and then the study of Vulnerability Analysis. The results of the study were used to direct the urban plan to set up the appropriate uses based on the study's findings,
The degrees of resistance of the areas to flood waters are evaluated, and the area's most at risk are identified using arcgis program to factor account them into the proposed uses, as in fig14.

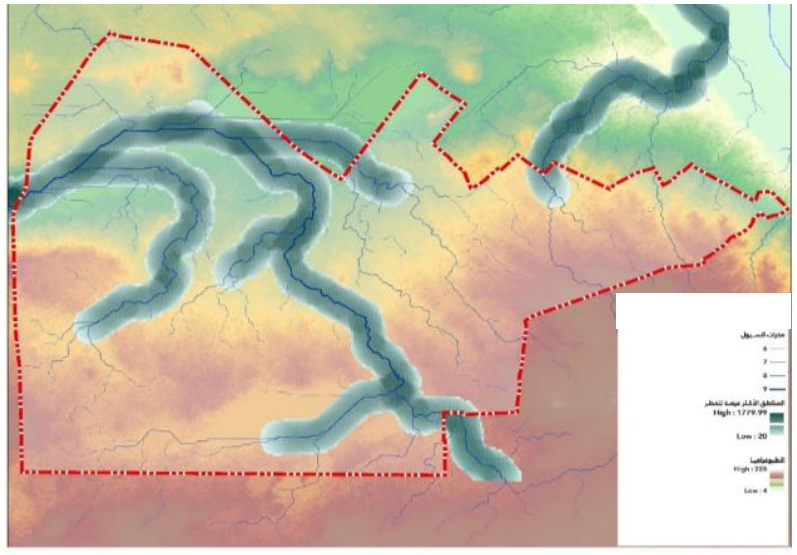

Fig14. The Vulnerability Analysis (V) using arcgis

\subsubsection{Third step: Environmental Risk assessment mapping}

The risk map was as determined by using a GIS program by compiling a vulnerability (v) map for (ecosystem services assessment of and the risk of torrential rain assessment), and the Hazard Analysis Risks (H), as shown in figure (15)

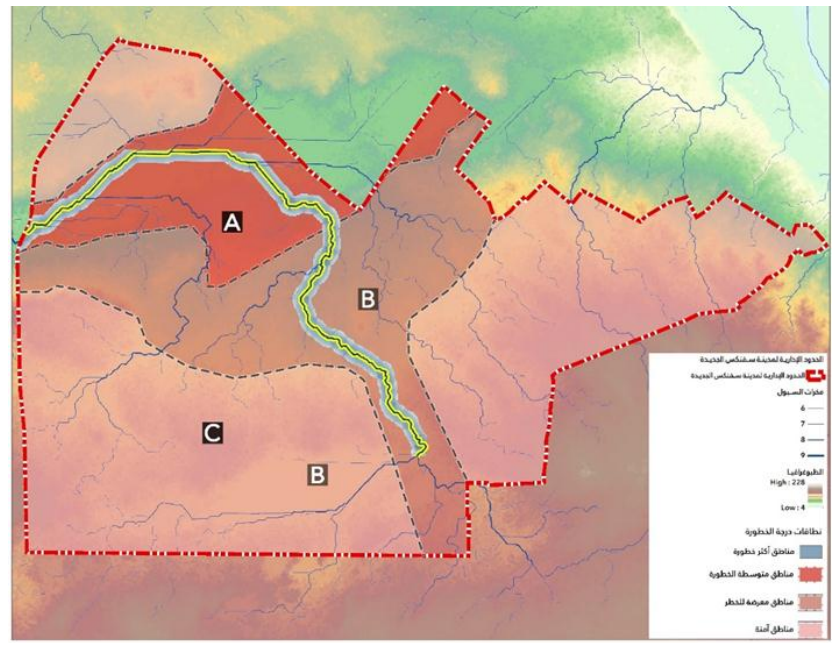

Fig15. Environmental Risk assessment mapping using ArcGIS

\section{Result and discussion}

3.1 Third phase: Suggested sustainable regulations for sustainable land use planning

After assessing the natural hazards (floods) in the study area, the considering environmental guidelines will be used to guide the plan as shown in fig15) and table (6) -Instructing the planner to avoid any future urban expansion in areas prone to flash floods.

-Choosing a site that is not directly in the path of known 
or predicted torrents

-The location should not be on cultivated land or land that is planned to be planted in the near

future while providing full protection for agricultural areas by totally preventing urban expansion to it and directing it away from it through various measures to preserve the agricultural region

-Instructing the planner to relocate the city's strategic points to safe areas

- Assist in identifying low-risk sites that require additional foundation standards to protect against the rush and impact of heavy rain.

- Using the street network in hazardous areas (as well as the agricultural drainage network) to apply to water paths in order to serve as water drainage channels during floods, while working to direct torrent water to the irrigation and drainage water network in the drained area, the expansion, and deepening of this network.

If absolutely necessary and as indicated by economic feasibility assessments for protection techniques, agricultural land can be used as a floor drain.

\subsection{Suggested environmental land uses alternatives for sustainable land use planning}

After assessing the risk-sensitive in the study area, and determine the sustainable land uses regulations, the considering Environmental land uses planning alternative will be used to guide planners to achieve sustainable land uses in new sphinx city, as shown in fig16. and table

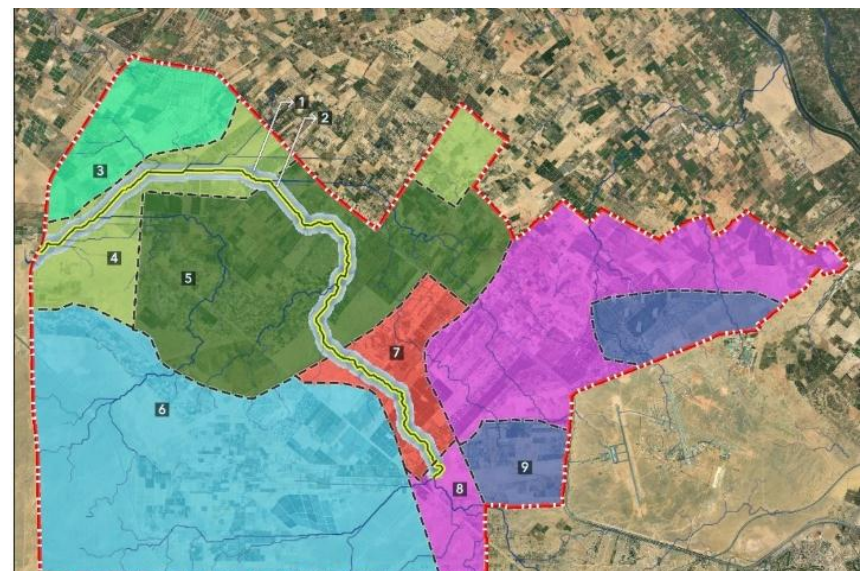

Fig 16. Sustainable land uses regulations and Environmental land uses planning
Table 6. Sustainable land uses regulations zoning for sustainable urban development

\begin{tabular}{|l|l|}
\hline ZONE & \multicolumn{1}{c|}{ Ecosystem characterizes } \\
\hline ZONE 1 & The flood buffer. \\
\hline ZONE 2 & $\begin{array}{l}\text { The flood buffer } \\
\text { High ecosystem services }\end{array}$ \\
\hline ZONE 3 & $\begin{array}{l}\text { High-risk areas } \\
\text { High ecosystem services } \\
\text { ZONE 4 } \\
\text { Medium risk areas }\end{array}$ \\
\hline ZONE 5 & $\begin{array}{l}\text { Safe areas } \\
\text { Low ecosystem services } \\
\text { Medium risk areas } \\
\text { High ecosystem services }\end{array}$ \\
\hline ZONE 6 & $\begin{array}{l}\text { Safe areas } \\
\text { Medium ecosystem services }\end{array}$ \\
\hline ZONE 8 & $\begin{array}{l}\text { Safe areas } \\
\text { Low ecosystem services }\end{array}$ \\
\hline ZONE 9 & \\
\hline
\end{tabular}

\begin{tabular}{|c|c|}
\hline ZONE & Recommendations and proposed landuses planning \\
\hline $\begin{array}{l}\text { ZONE } \\
1\end{array}$ & The flood buffer. \\
\hline $\begin{array}{l}\text { ZONE } \\
2\end{array}$ & The flood buffer is surrounded by green landscapes. \\
\hline $\begin{array}{l}\text { ZONE } \\
3\end{array}$ & $\begin{array}{l}\text { For its flat inclinations, which can be relied upon in the } \\
\text { settlement of agricultural activity, the land is } \\
\text { appropriate for a variety of uses without limitations or } \\
\text { barriers. }\end{array}$ \\
\hline $\begin{array}{l}\text { ZONE } \\
4\end{array}$ & $\begin{array}{l}\text { For its proximity to flood drains, the area is suitable for } \\
\text { specialized purposes, such as agricultural sectors - } \\
\text { residential use }\end{array}$ \\
\hline $\begin{array}{l}\text { ZONE } \\
5\end{array}$ & $\begin{array}{l}\text { For its flat characteristics, which can be depended upon } \\
\text { in the settlement of diverse uses, the area is appropriate } \\
\text { for numerous applications without limitations or } \\
\text { (residential - agricultural) }\end{array}$ \\
\hline $\begin{array}{l}\text { ZONE } \\
6\end{array}$ & $\begin{array}{l}\text { There are no limitations or constraints in the area, } \\
\text { making it appropriate for a variety of uses. It's also } \\
\text { known for its flat inclinations, which may be relied on in } \\
\text { the settlement of a variety of functions including } \\
\text { (industrial - residential - regional services) }\end{array}$ \\
\hline $\begin{array}{l}\text { ZONE } \\
7\end{array}$ & $\begin{array}{l}\text { For its flat characteristics, which can be depended upon } \\
\text { in the settlement of diverse uses, the area is suitable for } \\
\text { various uses without limitations or barriers (investment } \\
\text { areas) }\end{array}$ \\
\hline $\begin{array}{l}\text { ZONE } \\
8\end{array}$ & $\begin{array}{l}\text { There are no limitations or barriers in the area, making } \\
\text { it suitable for a variety of uses. It is also characterized } \\
\text { by its flat and high inclinations in comparison to the rest } \\
\text { of the study area, making it suitable for various of uses } \\
\text { (residential - agricultural) }\end{array}$ \\
\hline $\begin{array}{l}\text { ZONE } \\
9\end{array}$ & $\begin{array}{l}\text { There are no limitations or barriers in the area, making } \\
\text { it suitable for a variety of uses. It is also characterized } \\
\text { by its flat and high characteristics in comparison to } \\
\text { other parts of the study area, making it suitable for } \\
\text { variety of uses }\end{array}$ \\
\hline
\end{tabular}

\section{CONCLUSION}

It is be clarified that the principle of calculating ecosystems should be taken into account, especially calculating the extent of the ecosystem by calculating the current areas, additions and reductions, to monitor changes in the ecosystem resulting from the impact of risks on ecosystem services. So that Ecosystems can be effectively managed within the framework of sustainable land-use planning. Although it needs future research, it Should be noted that it is directly related to the research 
topic.

However, the existence of ecosystem services in the New Sphinx city is defined by the presence of ecosystem services in the city's agricultural lands, which total 40.5 thousand feddans and produce a variety of fruits and vegetables in addition to animal productivity., based on previous research into the city's current problems, that a lack of sufficient water resources to meet the city's needs, in addition to high levels of groundwater salinity reaching $2000 \mathrm{ppm}$, has harmed agricultural and animal production and will continue to do so in the future until agricultural ecosystem services return.

So, it is very important to evaluate risk (hazard, vulnerability), the vulnerability ecosystem services assessment results can support Risk assessment to achieve sustainable management of natural resources, environmental protection, spatial planning, and landscape planning; and can be applied to the development of nature-based solutions and environmental education.

Consequently, Environmental Risk-sensitive Land-use planning assessment may be recognized as a tool for the reduction of potential impacts on vulnerable areas, thus mitigating consequences of natural hazards as well as man-made technical disasters. By regulating the development and control of land use is a proactive mechanism for reducing vulnerability. The "plan" is the anticipation of a desirable future situation and should be based on a proper decision-making process.

Finally, the methodology of Environmental Risksensitive assessment is a more useful Environmental Land use planning assessment approach in Egyptian communities in order to ensure the sustainability integrated between the ecosystem services and risk assessment and to reach a set of environmental decisions in ensuring the sustainability of the management land uses.

\section{References}

[1] A. a. UDD, "Guidelines for Mainstreaming Disaster Risk Reduction into Land Use Planning for Upazilas and Municipalities in Bangladesh"," 2013.

[2] P. - Santos, "A comprehensive approach to understanding flood risk drivers at the municipal level.," J. Environ. Manag, Vols. 260, 110127. , 2020.

[3] M. Rogger, M. Agnoletti, A. Alaoui, J. Bathurst, G. Bodner, M. Borga, V. Chaplot, F. Gallart, G. Glatzel, J. Hall and e. al., "),Land use change impacts on floods at the catchment scale: Challenges and opportunities for future research," Water Resour. Res. , Vols. 53, 5209-5219. , 2017.

[4] H. J., "Risk as an economic factor," $Q J$ Econ.., vol. 9(4):409-449, p. 1895.

[5] R. P. M. Haines-Young, "Guidance on the Application of the Revised Structure (Guidance Document).," Common International Classification of Ecosystem Services (CICES), Fabis Consulting, Ltd, Nottingham, UK. , vol. V5.1, 2018.

[6] UNISDR, "Making Development SustainableThe Future of
Disaster Risk Management, Global Assessment Report on Disaster Risk Reduction," Geneva, Switzerland, United Nations Office for Disaster Risk Reduction., 2015.

[7] •. I. O. f. Standardization., " ISO 14001 Environmental management systems-requirements with guidance for use.," Geneva: ISO/TC 207/SC1, 2015.

[8] Y. Y. Q. Z. Deng F, "Research progresses of regional ecological risk assessment," Environ Sci Technol., p. 34(6G):141-147, 2011.

[9] A. Ciullo, A. Viglione, A. Castellarin, M. Crisci and G. ,. Di Baldassarre, "Socio-hydrological modelling of flood-risk dynamics: Comparing the resilience of green and technological system," s. Hydrol. Sci. J. , Vols. 62, 880-891, 2017.

[10] F. a. T. S. e. Klijn, "Comprehensive flood risk management:research for policy and practice.," CRC, Boca Raton, Florida, USA. , 2013.

[11] G. Aronica, A. Candela, P. Fabio and M. Santoro, "Estimation of flood inundation probabilities using global hazard indexes based on hydrodynamic variables," , . Phys. Chem. Earth Parts A/B/C, Vols. , 42, 119-129., 2020.

[12] W. B. a. EMI, "Risk-Sensitive Land Use Planning (RLUP) Guidebook,," Bangladesh Urban Earthquake Resilience Project ., p. 2015.

[13] P. B. Thapa, "Geo-disaster and risk sensitive land use planning in Nepal,", Bulletin of Nepal Geological Society,, vol. vol. 35, 2018.

[14] K. B. R. \&. L. J. Abhas, "Cities and Flooding: A Guide to Integrated Urban Flood Risk Management for the 21st Century.," The World Bank,Washington, D.C., USA , 2012.

[15] USAID, "Initial Environmental Examination (IEE) for Malawi," Secondary Education Expansion for Development (SEED)., vol. https://ecd.usaid.gov/repository/pdf/50453.pdf, 2017.

[16] J. - Birkmann, "Conclusions and recommendations. In: Measuring Vulnerability to Natural Hazards: Towards Disaster Resilient Societies," Vols. nited Nations University Press, Tokyo, Japan, no. pp. 432-447, 2006.

[17] UNISDR, "Making Development SustainableThe Future of Disaster Risk Management, Global Assessment Report on Disaster Risk Reduction,," United Nations Office for Disaster Risk Reduction. Geneva, Switzerland, , 2015.

[18] S. a. C. F. Cutter, "Temporal and spatial changes in social vulnerability to natural hazards.," Proceedings of the National Academy of Sciences, vol. 105(7), 2008.

[19] T. 2. Cannon, ": Vulnerability analysis, livelihoods and disasters. In: Risk 21: Coping with Risks Due to Natural Hazards in the 21st Century," Taylor and Francis Group, London, UK, pp. ,pp. 41-49., 2006.

[20] M. E. A. (MEA), "Ecosystems and Human Well-Being:," Synthesis. Island Press, Washington, DC, 2005.

[21] J. M. R. I. S. M. L. P. G. Z. .. J. Dick, "Cross-scale analysis of ecosystem services identified and assessed at local and European level," Ecological Indicators, Vols. 38, 20, 2014.

[22] Y. Abebe, A. Ghorbani, I. Nikolic, Z. Vojinovic and A. Sanchez, "Flood risk management in Sint Maarten-A coupled agent-based and flood modelling method.," $J$. Environ. Manag,, Vols. 248, 109317, 2019.

[23] Armoni, " Applied multi risk mapping of natural hazards for impact assessment, Global-2-51 Land Use Planning guidelines in the context of article 12 of," the Seveso II 
Directive 96/82/EC, 2003.

[24] M. S. P. a. H. M. Alexander, " A framework for evaluating flood risk governance.," Environmental Science and Policy, pp. 64:38-47. , 2016.

[25] Y. Kwak, B. Arifuzzanman and Y. P. p. Iwami, "roxy mapping of flood damaged rice fields using MODIS-derived indices.," Remote Sens. , 2015.

[26] The New Urban Communities Authority, "the general strategic plan for the new city of Sphinx.," 2020.

[27] M. K. S. S. T. 2. Abdel-Fattah, "Integrated management of flash flood in wadi system of Egypt: disaster prevention and water harvesting," A. Disas. Prev, Res. Inst. Kyoto Univ., vol. 58(B), pp. 485-496. . 